\title{
SPATIAL DEPENDENCE OF ELECTRICAL CONDUCTIVITY AND CHEMICAL PROPERTIES OF THE SOIL BY ELECTROMAGNETIC INDUCTION
}

\author{
Flavia Cristina Machado(1), Rafael Montanari ${ }^{(2)^{*}}$, Luciano Shozo Shiratsuchi ${ }^{(3)}$, Lenon \\ Henrique Lovera ${ }^{(4)}$ and Elizeu de Souza Lima ${ }^{(4)}$
}

(1) Universidade Estadual de Mato Grosso do Sul, Unidade de Aquidauana, Programa de Pós-graduação em Produção Vegetal, Aquidauana, Mato Grosso do Sul, Brasil.

(2) Universidade Estadual Paulista "Júlio de Mesquita Filho", Campus de Ilha Solteira, Departamento de Fitossanidade, Engenharia Rural e Solos, Ilha Solteira, São Paulo, Brasil.

(3) Empresa Brasileira de Pesquisa Agropecuária, Centro Nacional de Pesquisa Agrossilvipastoril, Sinop, Mato Grosso, Brasil.

(4) Universidade Estadual Paulista "Júlio de Mesquita Filho", Campus de Ilha Solteira, Programa de Pós-graduação em Sistemas de Produção, Ilha Solteira, São Paulo, Brasil.

*Corresponding author.

E-mail: montanari@agr.feis.unesp.br

\begin{abstract}
Brazilian soils have natural high chemical variability; thus, apparent electrical conductivity (ECa) can assist interpretation of crop yield variations. We aimed to select soil chemical properties with the best linear and spatial correlations to explain ECa variation in the soil using a Profiler sensor (EMP-400). The study was carried out in Sidrolândia, MS, Brazil. We analyzed the following variables: electrical conductivity - EC $(2,7$, and $15 \mathrm{kHz})$, organic matter, available $\mathrm{K}$, base saturation, and cation exchange capacity (CEC). Soil ECa was measured with the aid of an all-terrain vehicle, which crossed the entire area in strips spaced at $0.45 \mathrm{~m}$. Soil samples were collected at the $0-20 \mathrm{~cm}$ depth with a total of 36 samples within about 70 ha. Classical descriptive analysis was applied to each property via SAS software, and $\mathrm{GS}^{+}$for spatial dependence analysis. The equipment was able to simultaneously detect ECa at the different frequencies. It was also possible to establish site-specific management zones through analysis of correlation with chemical properties. We observed that CEC was the property that had the best correlation with ECa at $15 \mathrm{kHz}$.
\end{abstract}

Keywords: precision agriculture, electrical conductivity, management zones. 


\title{
RESUMO: DEPENDÊNCIA ESPACIAL DA CONDUTIVIDADE ELÉTRICA E ATRIBUTOS QUÍMICOS DO SOLO POR INDUÇÃO ELETROMAGNÉTICA
}

\begin{abstract}
Os solos brasileiros apresentam grande variabilidade quimica natural e com isso a condutividade elétrica aparente (CEa) pode auxiliar na interpretação das variações de produtividade das culturas. O objetivo deste trabalho foi selecionar atributos químicos do solo com a melhor correlação linear e espacial, para explicar a variabilidade da CEa do solo utilizando o aparelho Profiler modelo EMP-400. O estudo foi realizado no município de Sidrolândia, $M S$, e as variáveis avaliadas no solo foram: $C E 2 \mathrm{kHz}, \mathrm{CE}$ $7 \mathrm{kHz}, \mathrm{CE} 15 \mathrm{kHz}$, matéria orgânica, $K$ disponível, saturação de bases e capacidade de troca catiônica (CTC). A medição da CEa do solo foi feita com auxílio de um quadricículo, percorrendo a área total com espaçamento de 0,45 m entre passadas. As amostras de solo foram coletadas na profundidade de 0-20 cm, totalizando 36 amostras de solo em aproximadamente 70 ha. Para cada atributo analisado, realizou-se a análise descritiva clássica, utilizando o programa $S A S$, e para a dependência espacial, usou-se o GS+. O equipamento foi capaz de detectar simultaneamente as CEas nas diferentes frequências; por meio da análise de correlação com os atributos químicos do solo, foi possível estabelecer as zonas específicas de manejo. O atributo do solo que melhor se correlacionou com a CEa foi a CTC, para a frequência de $15 \mathrm{kHz}$.
\end{abstract}

Palavras-chave: agricultura de precisão, condutividade elétrica, zonas de manejo.

\section{INTRODUCTION}

Precision agriculture can be described as production management taking into account the spatial variability of yield and its related factors. It is a relatively new field of research in agricultural sciences, and provides promising perspectives for generation of new technology and crop management alternatives, as well as potential environmental benefits (Faulin, 2005).

Homogeneous areas within a field are difficult to identify due to the complex combination of factors that may influence crop yield. Correlations between yield (dependent variable) and production factors (e.g., soil fertility) are quite low (Molin et al., 2001); and attempts to explain local phenomena with few factors have been unsuccessful.

Several methods have been proposed to define management zones, among them, the use of topography, aerial photographs, crop canopy imaging, and remote sensing, in addition to crop yield mapping, which is currently most known among these sources of information (Molin, 2001).

Studies using soil apparent electrical conductivity (ECa) have shown potential in quantifying contents of clay (Williams and Hoey, 1987), water (Kachanoski et al., 1988), and salt in the soil solution (Caminha Junior et al., 2000); organic matter (Jaynes, 1996); cation exchange capacity and exchangeable $\mathrm{Ca}$ and $\mathrm{Mg}$ (McBride et al., 1990), and claypan depth (Doolittle et al., 1994; Clark et al., 2000), among others. Thus, it may be possible to measure the ECa rapidly and at low cost so as to georeference soil properties that affect crop yield (Bronson et al., 2005). Several types of equipment are commercially available for in situ measurement of ECa, for example, the MuCEP, the Veris 3100, the Soil Doctor, the EM 38, the GEM 300, and the Profiler EMP400.

Soil ECa is controlled by a series of factors, among which are salt content, clay mineralogy, soil moisture, and soil temperature (Brevik et al., 2006). Netto et al. (2007) observed significant correlation between $\mathrm{pH}$ and exchangeable $\mathrm{Na}$ concentration, confirming positive and significant correlation between ECa and soil salt content. King et al. (2005) used an electromagnetic current sensor in an experimental field at two periods in the year that exhibit extreme values for soil moisture, field capacity, and permanent wilting point, showing ECa stability in both situations, despite significant differences in absolute terms.

Measurement of spatial and time variability of soil properties influencing crop yield for the purpose of optimizing the use of natural resources, reducing costs, and improving soil quality is of utmost importance for technological advancement of agriculture (Montanari et al., 2010). Spatial variations may be analyzed via geostatistics, which allow maps to be drawn up marking off areas of site-specific management (Dalchiavon et al., 2013).

Geostatistical analysis is a tool for evaluating the spatial variability of assessed and mapped soil properties by kriging interpolation, or even from estimates of two variables that are correlated by co-kriging. They can be described as techniques that minimize the estimated variance by regression analysis, taking dependence among data distributed in space into account. Thus, kriging and co-kriging interpolations are strongly associated with models of fitted semivariograms, which may be exponential, spherical, or Gaussian, which can be evaluated by cross validation (Dalchiavon et al., 2013). Following this line, Profiler EMP400 equipment can assist 
in reducing the number of soil samples collected, and therefore build up site-specific areas of soil management for precision farming purposes.

Thus, the aims of this study were to select soil properties with the best linear and spatial correlations to explain soil ECa variability, and to collect ECa sampling data using the Profiler EMP-400 equipment.

\section{MATERIAL AND METHODS}

The study was performed during the second half of 2013 on the Ribeirãozinho farm in Sidrolândia,

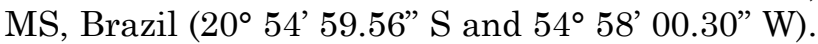
The study was carried in a field under conventional tillage and degraded grassland for 20 years. Soil at the location is classified as a Latossolo Vermelho distróférrico (Embrapa, 2013) (Oxisol) with $70 \%$ clay content. Data collection (ECa and soil) was done after corn harvest, when soil moisture was low. A georeferenced sketch was made containing 36 points randomly distributed to cover 70 ha of the field. Soil apparent electrical conductivity (ECa) was analyzed at three frequencies $(2,7$, and $15 \mathrm{kHz})$, chosen because they represent the upper, lower, and middle of the frequency range available for measurement. Measurements were performed by Profiler model EMP-400 (Geophysical Survey Systems, 2006) which crossed the entire area in strips spaced at $0.45 \mathrm{~m}$ at $1.0 \mathrm{~m}$ above the ground on a PVC support on an all-terrain vehicle. Regular soil samples were also collected from the area around each sampling point at the $0-20 \mathrm{~cm}$ depth layer for analysis of organic matter content - OM (2.6 \%), $\mathrm{pH}$ in $\mathrm{CaCl}_{2}$ (5.5), $\mathrm{P}$ $\left(2.9 \mathrm{mg} \mathrm{dm}^{-3}\right), \mathrm{S}\left(31.4 \mathrm{mg} \mathrm{dm}^{-3}\right), \mathrm{K}^{+}\left(3.6 \mathrm{mmol}_{\mathrm{c}} \mathrm{dm}^{-3}\right)$, $\mathrm{Ca}^{2+}\left(60.0 \mathrm{mmol}_{\mathrm{c}} \mathrm{dm}^{-3}\right), \mathrm{Mg}^{2+}\left(28.1 \mathrm{mmol}_{\mathrm{c}} \mathrm{dm}^{-3}\right)$, $\mathrm{H}+\mathrm{Al}\left(40.2 \mathrm{mmol}_{\mathrm{c}} \mathrm{dm}^{-3}\right), \mathrm{Al}^{3+}\left(1.4 \mathrm{mmol}_{\mathrm{c}} \mathrm{dm}^{-3}\right)$, sum of bases - SB $\left(91.8 \mathrm{mmol}_{\mathrm{c}} \mathrm{dm}^{-3}\right)$, cation exchange capacity - CEC $\left(132.1 \mathrm{mmol}_{\mathrm{c}} \mathrm{dm}^{-3}\right)$, base saturation - V (68.8\%), and aluminum saturation $\mathrm{m}\left(1.6 \mathrm{mmol}_{\mathrm{c}} \mathrm{dm}^{-3}\right)$, according to Raij et al. (2001). The analyses were made in the Sial Soil Laboratory in Campo Grande, MS, Brazil.

A classic descriptive analysis of the data was performed using SAS software (Schlotzhaver and Littell, 1997), in which the following numerical variables were calculated: mean, median, minimum, maximum, standard deviation, coefficient of variation, kurtosis, asymmetry, and frequency distribution. The Shapiro and Wilk test at $5 \%$ was used to test the hypothesis of normality or log-normality of exposure distribution. In addition, a simple correlation matrix was generated to identify parameters with collinearity in paired combinations of all the properties evaluated, which led to regression analyses for pairs of greatest interest.
Each property was separately evaluated in regard to spatial dependence through calculation of the simple semivariogram, based on the intrinsic stationary hypothesis, by Gamma Design Software $\left(\mathrm{GS}^{+}, 2004\right)$. Semivariogram sets were fitted in accordance with their models and were carried out primarily by initial selection of the lowest sum of squared deviations (SSD), the highest coefficient of determination $\left(\mathrm{R}^{2}\right)$, and the highest spatial dependence estimator (SDE). Final decision on the model that represented the fit was carried out by cross-validation, as well as for definition of the size of the neighboring area that provided a kriging mesh with the largest range, made by block kriging. The nugget effect $\left(\mathrm{C}_{0}\right)$, range $\left(\mathrm{A}_{\mathrm{o}}\right)$ and sill $\left(\mathrm{C}+\mathrm{C}_{\mathrm{o}}\right)$ were registered for each property. Analysis of the SDE was made by the following expression $\left(\mathrm{GS}^{+}, 2004\right)$ :

$\mathrm{SDE}=\left[\mathrm{C} /\left(\mathrm{C}+\mathrm{C}_{0}\right)\right] \times 100$

where SDE is the spatial dependence evaluator; $\mathrm{C}$, the structural variance; and $\mathrm{C}+\mathrm{C}_{0}$, the sill.

The proposed ranking was $\mathrm{SDE} \leq 20 \%$ - very low dependence, $20 \%<\mathrm{SDE} \leq 40 \%$ - low dependence, $40 \%<\mathrm{SDE} \leq 60 \%$ - medium dependence, $60 \%<\mathrm{SDE} \leq 80 \%$ - high dependence, and $80 \%<\mathrm{SDE} \leq 100 \%$ - very high dependence (Dalchiavon and Carvalho, 2012).

Cross-validation is a tool to assess alternative models of simple semivariograms for kriging. In this analysis, each point within the space is removed individually, and its value is estimated as if it did not exist. The correlation coefficient $(r)$ of such values shows the efficiency of fit, which is calculated by the sum of squared deviations, representing the linear regression equation in question. A regression coefficient of 1 represents a perfect fit, and the line of best fit would match the perfect model, i.e., with the linear coefficient equal to zero and the slope equal to $1\left(\mathrm{GS}^{+}, 2004\right)$. Thus, seeking an ideal number of neighboring points, we obtained, via interpolation, kriging maps to analyze spatial dependence and correlation of the properties. The geostatistical components determined for that purpose were the simple semivariogram, cross-validation, and kriging.

\section{RESULTS AND DISCUSSION}

The descriptive analysis of apparent electrical conductivity (ECa) of soil properties are shown in table 1. The ECa for the frequencies of 2 and $7 \mathrm{kHz}$ and base saturation $(\mathrm{V})$ had low variability, with the coefficient of variation ranging from -3.41 to $7.19 \%$. Bernardi et al. (2014), studying the spatial variability of ECa and soil chemical properties, found a different coefficient of variation for $\mathrm{ECa}$ 
compared to this study, which was considered very high for ECa (48.16\%). As for V, the value of the coefficient of variation was considered low (10\%). According to Pimentel-Gomes and Garcia (2002), the variability of a property may be classified according to the magnitude of its coefficient of variation, being designated as low (under $10 \%$ ), medium (from 10 to $20 \%$ ), high (between 20 and $30 \%$ ), and very high (above $30 \%$ ).

Soil chemical properties such as OM, K and CEC had a medium variability $-17.41,17.87$, and $16.24 \%$, respectively (Table 1 ). Alves et al. (2014), working with a Latossolo Vermelho-Escuro (Oxisol), also found medium values of 17 and $12 \%$ for $\mathrm{OM}$ and CEC, respectively; however, they found a high variability of $28 \%$ for $\mathrm{K}$ content. Dalchiavon et al. (2011), studying spatial variability of chemical properties in a Latossolo Vermelho distroférrico (Oxisol) found medium values of $13.9 \%$ for OM; for K and CEC, they found results of 38.5 and $24.5 \%$, respectively, similar to the present study.

When a statistical variable has normal frequency distribution, the most appropriate measure of the central tendency to represent it should be its mean; otherwise, it should be represented by the median (Dalchiavon et al., 2011). Therefore, we used the median as the measure of the central tendency to represent properties, since the properties had indeterminate frequency, with positive coefficients of asymmetry from 0.214 to 0.682 ; as well as a negative coefficient of symmetry of 0.290 . In contrast, the coefficient of kurtosis was positive for $\mathrm{V}(0.589)$, and for the other properties, it was negative, with values from -0.812 to -0.115 . However, the results were not significant by the Shapiro-Wilk test at $5 \%$ normality, since no variation was observed, and all values were smaller than 0.0001 (Table 1). Thus, indeterminate frequency distribution of the properties, as well as the magnitude of the coefficients of Kurtosis and asymmetry were generally in accordance with Dalchiavon et al. (2011), who observed indeterminate distribution for chemical properties in a Latossolo Vermelho distroférrico under a no-tillage system in Mato Grosso do Sul, Brazil.

ECa median values increased along with an increase in applied frequency, at $-324.10 \mathrm{dS} \mathrm{m}^{-1}$ for $2 \mathrm{kHz} ;-85.23 \mathrm{dS} \mathrm{m}^{-1}$ for $7 \mathrm{kHz}$, and $-34.39 \mathrm{dS} \mathrm{m}^{-1}$ for $15 \mathrm{kHz}$. Molin et al. (2005), studying the ECa of a soil measured via electromagnetic induction in a Latossolo Vermelho (Oxisol), found a median value of $-61.0 \mathrm{dS} \mathrm{m}^{-1}$ at $15 \mathrm{kHz}$, in disagreement with our study. For OM, K, V, and CEC, median values were $2.56 \%, 3.64 \mathrm{mmol}_{\mathrm{c}} \mathrm{dm}^{-3}, 69.08 \%$, and $132.67 \mathrm{mmol}_{\mathrm{c}} \mathrm{dm}^{-3}$, respectively (Table 1 ). The $\mathrm{OM}$ values are under the optimal value $(2.5 \%)$ as recommended by Raij et al. (2011). Yet for K, the value was appropriate, at $3.64 \mathrm{mmol}_{\mathrm{c}} \mathrm{dm}^{-3}$. These $\mathrm{OM}$ and $\mathrm{K}$ values are similar to those obtained by Dalchiavon et al. (2011), which were $2.5 \%$ and $5.0 \mathrm{mmol}_{\mathrm{c}} \mathrm{dm}^{-3}$, respectively. For its part, the V had a high median value of $69.08 \%$, corroborating Mattioni et al. (2013), who found a median of $70.7 \%$ in a Hapludox. For CEC, a median of $133 \mathrm{mmol}_{\mathrm{c}} \mathrm{dm}^{-3}$ was found, possibly due to the soil being a highly weathered Oxisol. Souza et al. (2006), Gomide et al. (2011) and Mattioni et al. (2013), studying the variability of chemical properties of Oxisols also found high median values of CEC of 106, 147, and $145 \mathrm{mmol}_{\mathrm{c}} \mathrm{dm}^{-3}$, respectively.

Correlations between ECa and soil chemical properties had greater significance for OM and CEC at 2, 7, and $15 \mathrm{kHz}$ (Table 2). All ECa correlations were positive, except for those with available $\mathrm{K}$, in which the correlation was inverted. As frequency increased, ECa correlation with the soil chemical properties also increased.

Castro (2004) found correlation coefficients of $0.74,0.81$, and 0.73 for CEC, $\mathrm{K}$, and V, respectively, when assessing ECa correlation with physical and

Table 1. Descriptive analysis of electrical conductivity of some chemical properties of a Latossolo Vermelho distroférrico (Oxisol) in Sidrolândia, MS

\begin{tabular}{|c|c|c|c|c|c|c|c|c|c|c|}
\hline \multirow{2}{*}{ Property $^{(1)}$} & \multirow{2}{*}{ Mean } & \multirow{2}{*}{ Median } & \multicolumn{2}{|c|}{ Value } & \multirow{2}{*}{$\mathrm{SD}^{(2)}$} & \multicolumn{3}{|c|}{ Coefficient } & \multicolumn{2}{|c|}{ Probability test $^{(3)}$} \\
\hline & & & Minimum & Maximum & & Variation & Kurtosis & Asymmetry & $\operatorname{Pr}<w$ & FD \\
\hline & & & & & & $\%$ & & & & \\
\hline $\mathrm{EC} 2 \mathrm{kHz}\left(\mathrm{dS} \mathrm{m}^{-1}\right)$ & -322.03 & -324.10 & -339.09 & -298.73 & 10.99 & -3.41 & -0.812 & 0.559 & $<0.0001$ & IN \\
\hline $\mathrm{EC} 7 \mathrm{kHz}\left(\mathrm{dS} \mathrm{m} \mathrm{m}^{-1}\right)$ & -83.84 & -85.23 & 90.80 & -73.12 & 5.31 & -6.33 & -0.785 & 0.682 & $<0.0001$ & IN \\
\hline EC $15 \mathrm{kHz}\left(\mathrm{dS} \mathrm{m}^{-1}\right)$ & -33.45 & -34.39 & -38.75 & -25.22 & 3.91 & -11.68 & -0.770 & 0.672 & $<0.0001$ & IN \\
\hline $\mathrm{OM}(\%)$ & 2.62 & 2.56 & 1.80 & 3.98 & 0.45 & 17.41 & -0.591 & 0.355 & $<0.0001$ & IN \\
\hline $\mathrm{K}\left(\mathrm{mmol}_{\mathrm{c}} \mathrm{dm}^{-3}\right)$ & 3.64 & 3.64 & 2.27 & 5.74 & 0.65 & 17.87 & -0.604 & 0.214 & $<0.0001$ & IN \\
\hline $\mathrm{V}(\%)$ & 68.98 & 69.08 & 52.89 & 82.78 & 4.96 & 7.19 & 0.589 & -0.290 & $<0.0001$ & IN \\
\hline $\operatorname{CEC~}\left(\mathrm{mmol}_{\mathrm{c}} \mathrm{dm}^{-3}\right)$ & 133.73 & 132.67 & 95.05 & 191.23 & 21.72 & 16.24 & -0.115 & 0.349 & $<0.0001$ & IN \\
\hline
\end{tabular}

(1) EC: electrical conductivity; OM, K, V, and CEC are organic matter, potassium, base saturation, and cation exchange capacity, respectively, at the $0-20 \mathrm{~cm}$ depth; ${ }^{(2)} \mathrm{SD}$ : standard deviation; ${ }^{(3)} \mathrm{FD}$ : frequency distribution, IN: indeterminate type. 
Table 2. Linear correlation matrix between electrical conductivity and some chemical properties of a Latossolo Vermelho distroférrico (Oxisol) in Sidrolândia, MS

\begin{tabular}{|c|c|c|c|c|c|c|}
\hline Property $^{(1)}$ & EC $2 \mathrm{kHz}$ & EC $7 \mathrm{kHz}$ & EC $15 \mathrm{kHz}$ & OM & $\mathbf{K}$ & $\mathbf{V}$ \\
\hline $\mathrm{EC} 7 \mathrm{kHz}$ & $0.943^{* *}$ & - & - & - & - & - \\
\hline EC $15 \mathrm{kHz}$ & $0.853^{* *}$ & $0.954^{* *}$ & - & - & - & - \\
\hline $\mathrm{OM}$ & $0.172^{* *}$ & $0.241^{* *}$ & $0.313^{* *}$ & - & - & - \\
\hline $\mathrm{K}$ & $-0.268^{* *}$ & $-0.261^{* *}$ & $-0.245^{* *}$ & $0.247^{* *}$ & - & - \\
\hline $\mathrm{V}$ & 0.082 & $0.149^{* *}$ & $0.237^{* *}$ & $0.403^{* *}$ & $-0.161^{* *}$ & - \\
\hline CEC & $0.561^{* *}$ & $0.672^{* *}$ & $0.778^{* *}$ & $0.550^{* *}$ & $-0.280^{* *}$ & $0.592^{* *}$ \\
\hline
\end{tabular}

(1) EC, OM, K, V, and CEC are electrical conductivity, organic matter, potassium, base saturation, and cation exchange capacity, respectively, collected at the $0-20 \mathrm{~cm}$ depth. $*$ and $* *$ : significant at 5 and $1 \%$, respectively.

(a)

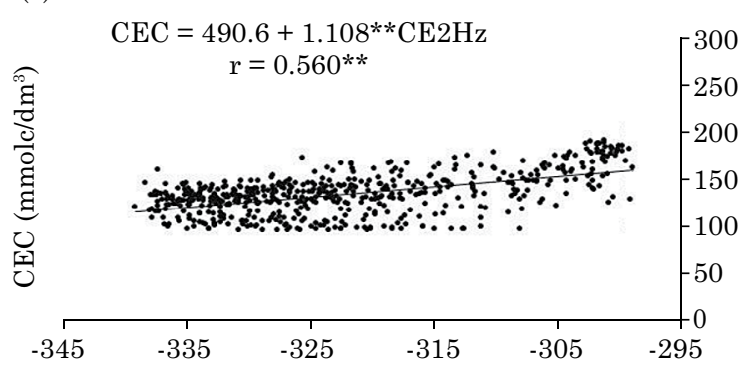

(c)

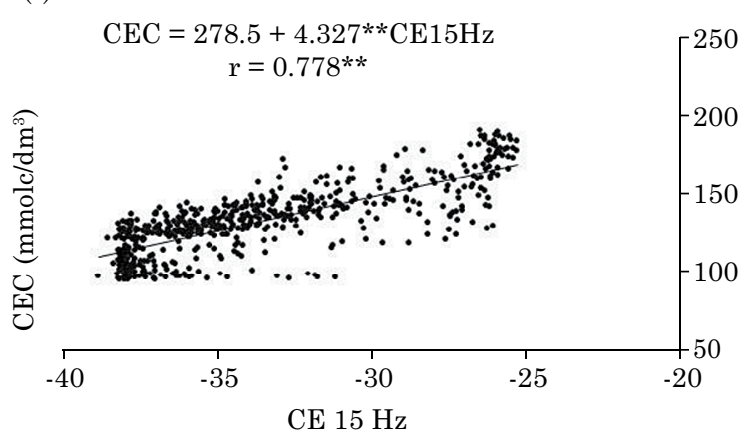

(e)

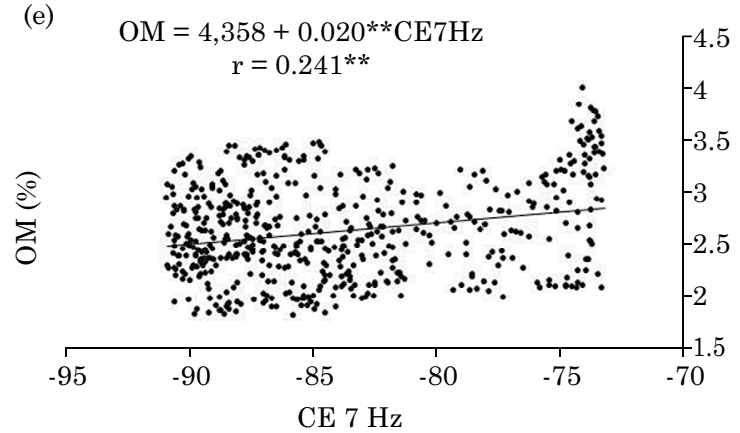

(b)

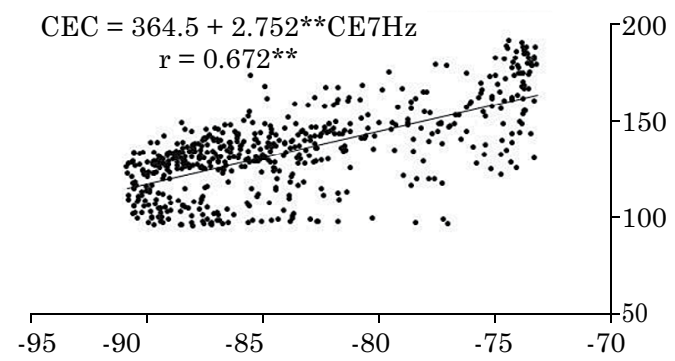

(d)

CE $7 \mathrm{~Hz}$

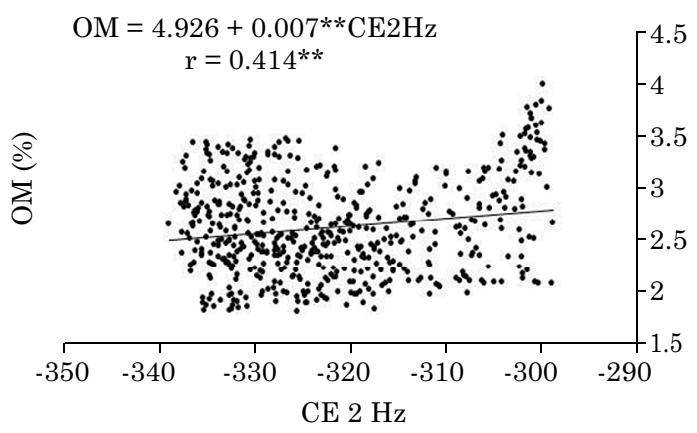

(f)

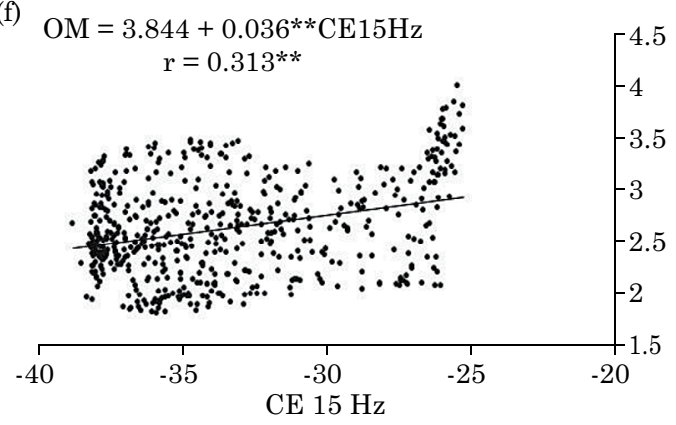

Figure 1. Regression equation between electrical conductivity and some chemical properties at the 0-20 cm depth of a Latossolo Vermelho distroférrico (Oxisol) in Sidrolândia, MS, Brazil. 
chemical properties of a Latossolo Vermelho-Escuro distroférrico (Oxisol). There was agreement with the present study only for the CEC property; the other coefficients were higher than the ones found in this study. Salton et al. (2011), working with ECa data in an Oxisol under conventional tillage, found correlation coefficients of 0.059 , $0.669,0.546$, and 0.160 for $\mathrm{K}, \mathrm{CEC}, \mathrm{V}$, and $\mathrm{MO}$, respectively, with values for the CEC properties and MO near those found in this study. Only for CEC, there was an agreement with our study, being the other properties higher than the ones found in this research. Salton et al. (2011), evaluating an Oxisol under conventional tillage, found correlation coefficients of $0.059,0.669,0.546$, and 0.160 for $\mathrm{K}$, CEC, V, and OM, respectively, with values for the CEC properties and OM near the ones found in this study.

Figure 1 shows the regression equations among the properties studied. For Hopkins (2000), coefficients of correlation higher than 0.5 indicate strong correlation, and below this value they are regarded as weak. Thus, figures $1 \mathrm{a}, 1 \mathrm{~b}$ and $1 \mathrm{c}$ indicate strong correlation, and figures $1 \mathrm{~d}, 1 \mathrm{e}$, and 1f shows correlations seen as weak, but still highly significant.

By geostatistical analysis, a spatial difference may be seen for all the properties studied (Table 3). The semivariograms of ECa 2 and $7 \mathrm{kHz}$ were fitted to the spherical model, $\mathrm{K}$ was fitted to the exponential model, and $\mathrm{ECa} 15 \mathrm{kHz}, \mathrm{OM}, \mathrm{V}$, and CEC were fitted to the Gaussian model. Freddi et al. (2009) found a Gaussian model for OM and V in a Latossolo Vermelho (Oxisol), corroborating this study. However, these authors found exponential and spherical models for K and CEC, respectively; which differed from the models listed in table 3. By comparing these models with those described by
Souza et al. (2006) in a Latossolo (Oxisol), there is only similarity for the $\mathrm{K}$ property, which also had a spherical model.

Regarding semivariogram performances, values of the spatial determination coefficient $\left(\mathrm{R}^{2}\right)$ in decreasing order were $\mathrm{V}(0.999), 2 \mathrm{kHz}(0.998), 7 \mathrm{kHz}$ (0.996), CEC (0.996), $15 \mathrm{kHz}$ (0.993), OM (0.993), and $\mathrm{K}$ (0.982). Concerning SDE, the strong dependence $(\mathrm{SDE}=99.9 \%)$ found in this study is similar to that observed by Dalchiavon et al. (2012), of $92.1 \%$, but it was best fitted to a spherical model.

Table 3 shows the values of range, in decreasing order, which were $7 \mathrm{kHz}(1,229 \mathrm{~m}), 2 \mathrm{kHz}(1,095 \mathrm{~m})$, $15 \mathrm{kHz}(1,002 \mathrm{~m}), \mathrm{K}(954 \mathrm{~m})$, CEC $(905 \mathrm{~m}), \mathrm{OM}$ $(431 \mathrm{~m})$, and V $(363 \mathrm{~m})$. Based on these results, further studies that use geostatistical meshes and distances between points similar to the ones used in this study are suggested. Moreover, range values to be used in geostatistical evaluations in precision agriculture, in general, should be from 431 to $1,229 \mathrm{~m}$, since this variation represents the distance within which values of a given property are equal (Cambardella et al., 1994; Campos et al., 2007; Martins et al., 2009; Dalchiavon et al., 2011).

When comparing the kriging maps (Figure 2), a spatial similarity among ECa at 2, 7, and $15 \mathrm{kHz}$ can be noted. Thus, in figures $2 \mathrm{a}, 2 \mathrm{~b}$, and $2 \mathrm{c}$, the lowest values of ECa (-43.5 -337 $\left.\mathrm{dS} \mathrm{m}^{-1}\right)$ were seen within the northern region. However, the highest values observed for OM were within the central region (Figure 2d). By comparing the maps of ECa, it can be concluded that the highest values of $\mathrm{OM}$ and ECa were seen separately for the southern region (Figures $2 \mathrm{a}, 2 \mathrm{~b}, 2 \mathrm{c}, 2 \mathrm{~d}$ ). Yet in figure $2 \mathrm{e}$, $2 \mathrm{f}$, and $2 \mathrm{~g}$, the highest values were found in the western, eastern, and eastern regions of the maps, respectively, representing most of the area.

Table 3. Fit parameters of the semivariograms and cross-validation for electrical conductivity and some chemical properties of a Latossolo Vermelho distroférrico in Sidrolândia, MS

\begin{tabular}{|c|c|c|c|c|c|c|c|c|c|c|c|}
\hline \multirow{2}{*}{ Property $^{(1)}$} & \multirow{2}{*}{ Model } & \multirow{2}{*}{$\mathbf{C}_{\mathrm{o}}$} & \multirow{2}{*}{$\mathrm{C}+\mathrm{C}_{\mathrm{o}}$} & \multirow{2}{*}{$A_{o}$} & \multirow{2}{*}{$\mathbf{R}^{2}$} & \multirow{2}{*}{$\operatorname{SSR}^{(2)}$} & \multicolumn{2}{|c|}{$\mathrm{SDE}^{(3)}$} & \multicolumn{3}{|c|}{ Cross-validation } \\
\hline & & & & & & & $\%$ & Class & $\mathbf{a}$ & $\mathbf{b}$ & $\mathbf{r}$ \\
\hline & & & & $\mathrm{m}$ & & & & & & & \\
\hline $\mathrm{EC} 2 \mathrm{kHz}$ & Spherical & 8.10 & $1.68 \times 10^{2}$ & 1,095 & 0.998 & $1.34 \times 10^{2}$ & 95.2 & $\mathrm{VH}$ & -1.38 & 0.996 & 0.917 \\
\hline $\mathrm{CE} 7 \mathrm{kHz}$ & Spherical & $3.0 \times 10^{-1}$ & $4.30 \times 10$ & 1,229 & 0.996 & $1.49 \times 10$ & 99.3 & $\mathrm{VH}$ & -0.55 & 0.994 & 0.951 \\
\hline $\mathrm{CE} 15 \mathrm{kHz}$ & Gaussian & 2.32 & $2.34 \times 10$ & 1,002 & 0.993 & 8.06 & 90.1 & VH & 1.95 & 1.058 & 0.947 \\
\hline $\mathrm{OM}$ & Gaussian & $1.0 \times 10^{-4}$ & $2.48 \times 10^{-1}$ & 431 & 0.993 & $8.84 \times 10^{-4}$ & 100 & VH & 0.00 & 1.000 & 0.998 \\
\hline $\mathrm{K}$ & Exponential & $1.0 \times 10^{-3}$ & $4.94 \times 10^{-1}$ & 954 & 0.982 & $6.29 \times 10^{-3}$ & 99.8 & $\mathrm{VH}$ & -0.11 & 1.029 & 0.992 \\
\hline V & Gaussian & $2.0 \times 10^{-2}$ & $2.107 \times 10$ & 363 & 0.999 & $6.05 \times 10^{-1}$ & 99.9 & VH & -0.08 & 1.001 & 0.998 \\
\hline CEC & Gaussian & $3.3 \times 10$ & $6.96 \times 10^{2}$ & 905 & 0.996 & $3.78 \times 10^{3}$ & 95.3 & VH & -3.15 & 1.024 & 0.994 \\
\hline
\end{tabular}

(1) EC, OM, K, V, and CEC are electrical conductivity, organic matter, potassium, base saturation, and cation exchange capacity, respectively, collected at the $0-20 \mathrm{~cm}$ depth; ${ }^{(2)} \mathrm{SSR}$ : sum of squared residue; ${ }^{(3)} \mathrm{SDE}$ : spatial dependence evaluator, where VH: very high. 

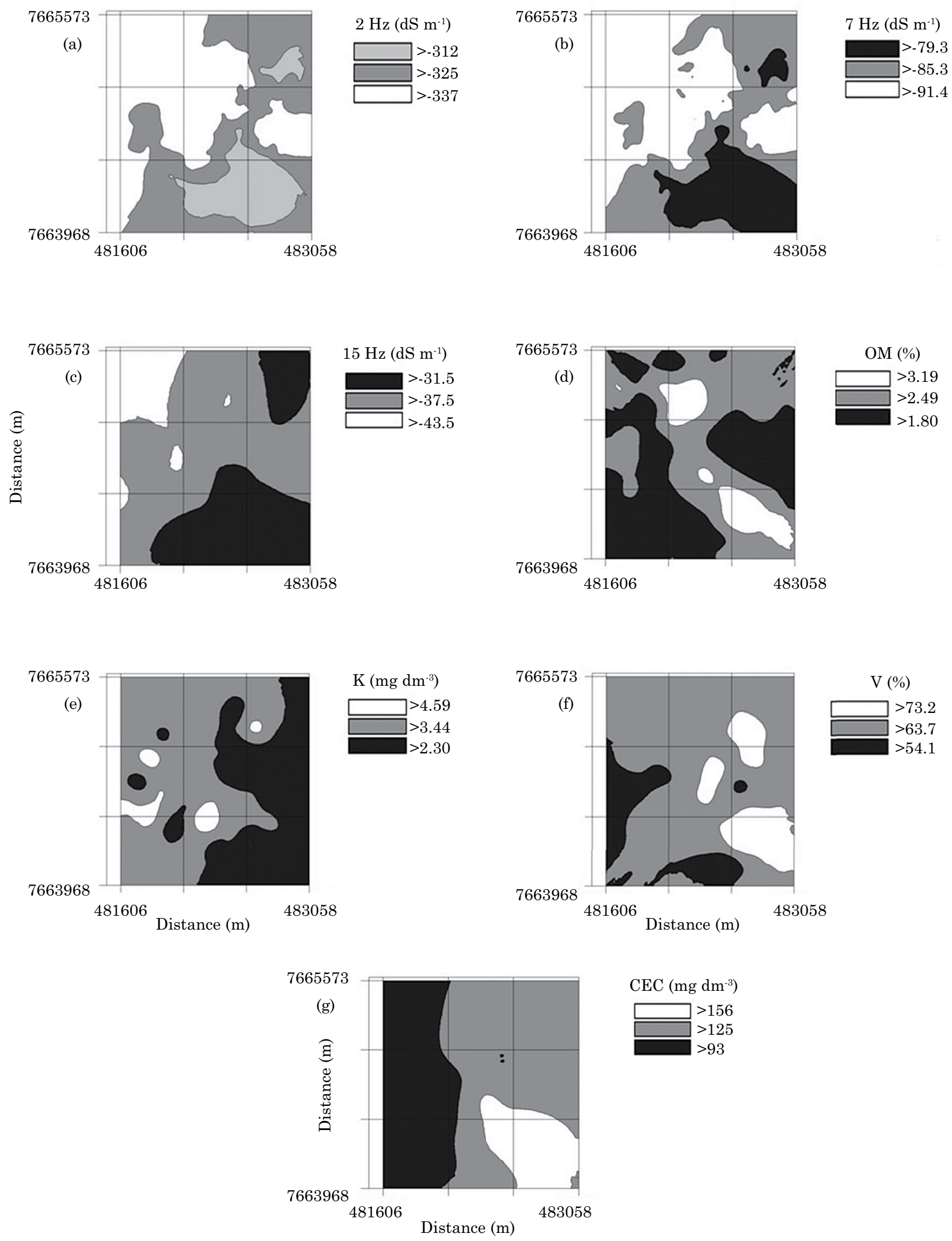

Figure 2. Kriging maps of electrical conductivity of some chemical properties at the 0-20 cm depth of a Latossolo Vermelho distroférrico (Oxisol) in Sidrolândia, MS, Brazil. 


\section{CONCLUSIONS}

The properties of apparent electrical conductivity (ECa) at 2,7 , and $15 \mathrm{kHz}$, organic matter, available $\mathrm{K}$, base saturation, and cation exchange capacity did not vary at random and exhibited low to medium linear data variability.

CEC was the soil property with the greatest correlation with $\mathrm{ECa}$, and among the frequencies studied, $15 \mathrm{kHz}$ had the highest correlation.

The properties ECa $(2,7$, and $15 \mathrm{kHz}), \mathrm{OM}, \mathrm{K}$, $\mathrm{V}$, and CEC exhibited spatial variability of the data and spatial dependence ranges from 363 to $1,229 \mathrm{~m}$.

The EMP-400 Profiler equipment was capable of detecting ECa's at various frequencies simultaneously and, through correlation analysis with soil chemical properties, it was possible to establish homogeneous zones for site-specific soil management.

\section{REFERENCES}

Alves SMF, Queiroz DM, Alcântara GR, Reis EF. Variabilidade espacial de atributos físico-químicos do solo usando técnicas de análise de componentes principais e geoestatística. Biosci J. 2014;30:22-30

Bernardi ACC, Rabello LM, Inamasu LY, Grego CR, Andrade RG. Variabilidade espacial de parâmetros físico-químicas do solo e biofísicos de superfície em cultivo do sorgo. R Bras Eng Agríc Amb. 2014;18:623-30.

Brevik E, Fenton T, Lazari A. Soil electrical conductivity as a function of soil water content and implications for soil mapping. Precision Agric. 2006;7:393-404.

Bronson K, Booker J, Officer S, Lascano R, Maas S, Searcy S, Booker J. Apparent electrical conductivity, soil properties and spatial covariance in the U. S. Southern High Plains. Precision Agric. 2005;6:297-311.

Cambardella CA, Moorman TB, Novak JM. Field-scale variability of soil properties in central Iowa soils. Soil Sci Soc Am J. 1994;58:1501-11.

Caminha Junior IC, Seraphim OJ, Gabriel LRA. Caracterização de uma área agrícola irrigada com efluente agroindustrial, através de análises químicas e da resistividade do solo. Energ Agric. 2000;13:40-54.

Campos MCC, Marques Júnior J, Pereira GT, Montanari R, Siqueira DS. Variabilidade espacial da textura de solos de diferentes materiais de origem em Pereira Barreto, SP. R Ci Agron. 2007;38:148-57.

Castro CN. Definição de unidades de gerenciamento de solo por meio de sua condutividade elétrica e variáveis físico-químicas [dissertação]. Piracicaba: Escola Superior de Agricultura Luiz de Queiroz; 2004.

Clark RL, Chen F, Kissel DE, Adkins W. Mapping soil hardpans with the penetrometer and electrical conductivity. In: Proceedings of the $5^{\text {th }}$ International Conference on Precision Agriculture [CD-ROM]; 2000; Minneapolis. Minneapolis: 2000.
Dalchiavon FC, Carvalho MP, Andreotti M, Montanari R. Variabilidade espacial de atributos da fertilidade de um Latossolo Vermelho Distroférrico sob Sistema Plantio Direto. R Ci Agron. 2012;43:453-61.

Dalchiavon FC, Carvalho MP, Freddi OS, Andreotti M, Montanari R. Variabilidade espacial da produtividade do feijoeiro correlacionada com atributos químicos de um Latossolo Vermelho distroférrico sob sistema de semeadura direta. Bragantia. 2011;70:1-9

Dalchiavon FC, Carvalho MP, Montanari R, Andreotti M. Strategy of specification of management areas: rice grain yield as related to soil fertility. $\mathrm{R}$ Bras Ci Solo. 2013;37:45-54.

Dalchiavon FC, Carvalho MP. Correlação linear e espacial dos componentes de produção e produtividade da soja. Semina: Ci Agron. 2012;33:541-52.

Doolittle JA, Sudduth KA, Kitchen NR Indorante SJ. Estimating depths to clay pans using electromagnetic induction methods. J Soil Water Conserv. 1994;49:572-5.

Empresa Brasileira de Pesquisa Agropecuária - Embrapa. Sistema brasileiro de classificação de solos. $3^{\text {a }}$.ed. Brasília: Embrapa Solos; 2013.

Faulin GDC. Variabilidade espacial do teor de água, sua influência na condutividade elétrica do solo [dissertação]. Piracicaba: Escola Superior de Agricultura Luiz de Queiroz; 2005.

Freddi OS, Centurion JF, Duarte AP, Peres FSC. Compactação do solo e produção de cultivares de milho em Latossolo Vermelho. II - Intervalo hídrico ótimo e sistema radicular. $\mathrm{R}$ Bras Ci Solo. 2009;33:805-8

Geophysical Survey Systems. Profiler EMP-400. Nashua, NH, [US]: The World Leader in Subsurface Imaging; 2006.

Gomide PHO, Silva MLN Soares CRFS. Atributos físicos, químicos e biológicos do solo em ambientes de voçorocas no município de Lavras - MG. R Bras Ci Solo. 2011;35:567-77.

$\mathrm{GS}^{+}$: Geostatistics for environmental sciences. $7^{\text {th }}$.ed. Plainwell: Gamma Desing Software; 2004.

Hopkins WG. Correlation coefficient: a new view of statistics. 2000. [Accessed Apr 18, 2000] Available at: http://sportsci.org/resource/stats.

Jaynes DB. Improved soil mapping using electromagnetic induction surveys. In: Proceedings of the $3^{\text {rd }}$ International Conference on Precision Agriculture; 1996; Minneapolis. Minneapolis: 1996

Kachanoski RG, Gregorich EG, van wesenbeck IJ. Estimating spatial variations of soil water content using noncontacting eletromagnetic inductive methods. Can J Soil Sci. 1988;68:715-22.

King J, Dampney P, Lark R, Wheeler H, Bradley R, Mayr T. Mapping potential crop management zones within fields: use of yield map series and patterns of soil physical properties identified by electromagnetic induction sensing. Precision Agric. 2005;6:167-81.

Martins MV, Carvalho MP, Andreotti M, Montanari R. Correlação linear e espacial entre a produtividade do feijoeiro e atributos físicos de um Latossolo Vermelho distroférrico de Selvíria, Estado de Mato Grosso do Sul. Acta Sci Agron. 2009;31:147-54.

Mattioni NM, Schuch LOB, Villela FA. Variabilidade espacial e efeito de atributos químicos de um Latossolo na população de plantas e produtividade da cultura da soja. R Fac Zootec Veter Agron. 2013:19:20-32 
Mcbride SD, Nguyen ML, Rickard DS. Implications of ceasing annual superphosphate topdressing applications on pasture production. Proc New Zeal Grassland Assoc. 1990;46:199-202.

Molin JP, Couto HTZ, Gimenez LM, Pauletti V, Molin R, Vieira SR. Regression and correlation analysis of grid soil data versus cell spatial data. In: Proceedings of the $3^{\text {rd }}$ European Conference on Precision Agriculture [CD-ROM]; 2001; Montpelier. Montpelier: AgroMontpelier; 2001.

Molin JP, Gimenez LM, Pauletti V, Schmidhalter U, Hammer J. Mensuração da condutividade elétrica do solo por indução e sua correlação com fatores de produção. Eng Agríc. 2005;25:420-6.

Montanari R, Carvalho MP, Andreotti M, Dalchiavon FC, Lovera LH, Honorato MAO. Aspectos da produtividade do feijão correlacionados com atributos físicos do solo sob elevado nível tecnológico de manejo. R Bras Ci Solo. 2010;34:1811-22.

Netto AOA, Gomes CCS, Lins CCV, Barros AC, Campeche LFSM, Blanco FF. Características químicas e salino-sodicidade dos solos do perímetro irrigado Califórnia, SE, Brasil. Ci Rural. 2007;37:1640-5.
Pimentel-Gomes FP, Garcia CH. Estatística aplicada a experimentos agronômicos e florestais. Piracicaba: FEALQ; 2002.

Raij B van, Andrade JC, Cantarella H, Quaggio JA. Análise química para avaliação da fertilidade de solos tropicais. Campinas: Instituto Agronômico de Campinas; 2001.

Raij Bvan. Fertilidade do solo e manejo de nutrientes. Piracicaba: IPNI, 2011.

Salton JC, Tomazi M, Comunello E, Zanatta JÁ, Rabello L. Condutividade elétrica e atributos físicos e químicos de um Latossolo após 15 anos sob sistemas de manejo em Mato Grosso do Sul. In: Inamasu RY, Naime JM, Resende AV, Bassoi LH, Bernardi ACC, editores. Agricultura de precisão: um novo olhar. São Carlos: Embrapa Instrumentação, 2011. p.254-60.

Schlotzhaver SD, Littell RC. SAS system for elementary statical analysis. $2^{\mathrm{n}}$ d.ed. Cary: SAS Institute; 1997.

Souza ZM, Marques Júnior J, Pereira GT, Montanari M. Otimização amostral de atributos de Latossolos considerando aspectos solo-relevo. Ci Rural. 2006;36:829-36.

Williams BG, Hoey D. The use of electromagnetic induction to detect the spatial variability of the salt and clay content of soils. Aust J Soil Res. 1987;25:21-7. 